\title{
Towards a Historical Materialist Approach to Racism in Post-'Unification' Germany
}

\author{
Juliane Edler York University
}

\begin{abstract}
Résumé
Le présent article cerne les problèmes liés au sous-texte de la « race », qui régit le processus contradictoire d'« unification » de l'Allemagne. Ma recherche est axée sur la question suivante : comment et quand les travailleurs est-allemands «blancs » de l'Allemagne réunifiée en sont-ils venus à percevoir leur caractère «allemand / / blanc » comme porteur de sens? En m'inspirant du travail de David R. Roediger, j'avance que les travailleurs estallemands «blancs » ont bénéficié du « salaire de l'allemanité ». C'est un concept qui s'étoffe lors de l'exploration de trois dimensions interreliées des changements marquant l'expérience vécue des travailleurs est-allemands («blancs ») : 1) la réglementation de la citoyenneté allemande, avec ses lignes d'inclusion et d'exclusion; 2) le qualificatif «Est » indiquant l'existence de différents degrés d'allemanité; 3) une dépendance individualisée par rapport au marché suscitant des émotions conflictuelles. L'« unification » a déclenché un processus de changement majeur et complexe qui a eu des répercussions sur les rapports sociaux de pouvoir, les expériences vécues et les moyens culturels. Le concept de « salaire de l'allemanité » exprime les liens entre les aspects politique, idéologique et économique de l'« unification »; il cristallise, en outre, l'héritage historique de notions racialisées de l'allemanité. Dans l'optique du matérialisme historique, le présent article élabore une critique de l'idéologie hégémonique, qui infère que, dans l'Allemagne réunifiée, le racisme s'est essentiellement restreint, dans l'espace, à l'Allemagne de l'Est.
\end{abstract}

\footnotetext{
Abstract

This paper problematizes the subtext of 'race', which underpinned the contradictory process of German 'unification'. The following question guides my inquiry: how and why have 'white' East German workers in post-'unification' Germany come to think of their 'Germanness'/'whiteness' as meaningful? Clearly drawing from the work of David R. Roediger, I argue that 'white' East German workers were paid the 'wages of Germanness'. The concept is fleshed out as I interrogate three interrelated dimensions of changes pertaining to the lived experiences of ('white') East German workers: (1) German citizenship regulations with its lines of inclusion and exclusion; (2) the qualifier East denoting the existence of various degrees of Germanness; (3) individualized market dependence giving rise to conflicted emotions. Setting in motion a process of extensive and
} 
complex change, 'unification' had an impact on social relations of power, lived experiences and cultural means. The concept 'wages of Germanness' expresses the connections between political, ideological and economic aspects of 'unification', and further brings into focus the historical legacy of racialized notions of Germanness. Using the framework of historical materialism, this paper articulates a critique of hegemonic ideology, which suggests that racism in post-'unification' Germany was, by and large, spatially confined to East Germany.

a reunited germany celebrates itself in 1990 without its immigrants, refugees, jewish and black people it celebrates in its intimate circle

it celebrates in white

(Opitz, 1992: 232)

\section{Introduction}

German unification - this term carries with it a heavy bag of contradictory meanings that speak of a contradictory reality. In 1989/1990, it was in its hegemonic meaning first and foremost a festive and cheerful idiom: East Germans were hailed as the brothers and sisters' of West Germans, ${ }^{1}$ or were they? Who exactly was and who was not considered a member of this national family about to be reunited? Giving voice to "those who always are, were, and shall remain the 'others"', the activist, research scholar, poet, essayist and self-identified Afro-German May Ayim articulates a forewarning in 1990: "the actual others declare on us", she writes, "war" (Opitz, 1992: 232). The opening quote, lines taken from the same poem, illustrates pointedly that the spectre of white supremacy was haunting Germany, a spectre that would soon ride the wave of familial/national celebration.

When writing about racism in Germany, I found myself inevitably confronted with the contradictions inherent in the term 'German'. The hegemonic meaning of 'Germanness' denotes a form of racialization. Here, a nationalistic language conveys the subtext of 'race'. Without being spoken, the meaning of 'race' might still be conveyed. Other terms have come to transport the meaning of 'race' as well as 'whiteness' - e.g. the terms Volk and 'German' (Guillaumin, 2000). I saw myself confronted with the necessity to find a terminology, which reflects the fact that the hegemonic idea of Germanness is inextricably intertwined with nationalistically framed processes of racialization. For now, I have decided to use quotation marks throughout this essay to indicate the problematic character of terms such as 'race', 'white' or 'whiteness'. By doing so, I want to call attention to the

\footnotetext{
${ }^{1}$ Throughout this paper, I use the term East German to refer to the territory as well as the people of what used to be the GDR (German Democratic Republic) and the term West German to refer to the territory as well as the people of what used to be the FRG (Federal Republic of Germany) prior to the accession (Beitritt) of the GDR.
} 
fact that these terms - like the term 'German' when it refers to the idea of a German nation - denote constructions. Through the use of the terminology 'whiteGermans', I want to emphasize and explicate the racialized underpinnings of Germanness.

The openly violent form of racism in the early $1990 \mathrm{~s}^{2}$ seemed to catch by surprise many 'whiteGermans' who had not been conscious of the racialized character of the family gathering. But here it was, an issue that had been repressed - more or less successfully and surely in different ways - in both German states: a racialized notion of Germanness. The latter had blossomed previously in the colonial and fascist past, yet a critical reflection on this legacy had been truncated. After WWII, hegemonic ideologies in West and East Germany had (albeit for quite different reasons) declared discussions of 'race' and racism a taboo. Was this taboo to be broken now that Germany was about to return to a state of 'normalcy'? Was critical reflection on the legacy of this racialized idea of Germanness going to put an end to the ('white') celebration?

The 1990s would pass without a broad-based critical and self-reflexive examination of the various forms of racism within Germany. Indeed, a recent ground-breaking anthology on critical whiteness studies in Germany (Eggers et al., 2005) leaves no doubt that the proximity of 'Germanness' and 'whiteness' remains largely unacknowledged. But how has it been possible within the German mainstream to continuously evade self-criticism? To begin with, the list of suspects is severely restricted. On the one hand, many strategies of evasion are built on a rather limited conception of racism. Institutional as well as the everyday forms of racism are often occluded as the debate centres on racist physical violence and right-wing voting behaviour. On the other hand, a shift has occurred within hegemonic ideology that is inextricably intertwined with 'unification'. ${ }^{3}$ The latter has supposedly confirmed the superiority of the West German political system and its economic power. Not unrelated, racism has been constructed as an exclusively East German problem ${ }^{4}$ which, pleasantly, leaves untouched the sense of 'whiteWestGerman' superiority. But as the burden of racism (in its limited sense) is slipped onto the shoulders of East Germans,

\footnotetext{
${ }^{2}$ For example, there was Hoyerswerda in September 1991, Rostock-Lichtenhagen in August 1992, Mölln in November 1992, and Solingen in May 1993.

${ }^{3}$ I share with other authors certain reservations regarding the term unification, which has been given expression in an alternative terminology such as the "absorption of East Germany" (Callinicos, 1991: 91) or "the annexation of its [the GDR's] territory by the FRG" (Rosenberg, 1991b: 129). Throughout this essay, I use inverted commas to signal the problematic character of the term unification.

${ }^{4}$ This practice materialized, for example, in many instances related to Germany hosting the World Cup in June/July of 2006. The hegemonic ideology claims that the origins of racism/right-wing extremism in post-'unification' Germany could be located, by and large, in East Germany and are thus allegedly external to West German society. Upholding such a view is possible because, among other things, the mainstream media continuously ignores empirical facts that run counter to such a view. For example, the social scientist Thomas Ahbe cites a statistic of the Ministry of Internal Affairs that has been subject to such occlusive practices: listing the German provinces (Bundesländer) according to the number of racially motivated criminal offences per resident, four West German provinces are ranked higher than any East German province (Ahbe, 2000).
} 
the conflation of 'Germanness' and 'whiteness' - which the opening quote so eloquently captures - vanishes from sight.

Various authors concerned with the racial subtext of 'unification' have pointed to the process of re-configuring complex social relations that was set in motion when the Berlin Wall came down in 1989 (Ayim, 1993; Çil, 2005). Part of this process was the emergence of a historically specific idea of Germanness. In this paper, I want to begin to theorize the tensions and dynamics that arise due to three aspects of this idea of Germanness. First, the idea of Germanness is racialized - as in 'whiteGermans'. Second, the idea of Germanness encompasses various degrees of Germanness. For example, the heavy reliance on the qualifier East (as in East Germans) marks a hierarchical ordering within the category 'whiteGerman'. Third, the meaning of the idea of ('white') Germanness from the perspective of 'white' East German workers cannot be grasped without its relation to their new experience of individualized market dependence. To be clear, one of the central aims of this paper is to dislocate the notion that racism in post-'unification' Germany could be spatially confined to East Germany. If I focus here on 'white' East German workers, I do so because I want to dislocate this hegemonic ideology and criticize the widely accepted underlying assumptions. Due to the different post-WWII histories in East and West Germany it is necessary to distinguish the lived experiences of working people in the GDR and in the FRG. Theorizing racism in the early 1990s thus requires that the changes pertaining to the lived experiences of 'white' East German workers are theorized in their historical specificity.

I begin with a section on my theoretical framework. Then, I move on to a discussion of citizenship and the racialized idea of ('white') Germanness. The third section focuses on the qualifier East. Finally, the fourth section problematizes the meaning of individualized market dependence as it relates to the lived experience of 'white' East German workers in the early 1990s. The overarching question that guides this paper is how and why 'white' East German workers have come to prize their 'whiteGermanness' and to think of it as meaningful. By asking this question, I take a step towards using my 'white' position to demystify the complex system of 'white' privilege in post-'unification' Germany (Wachendorfer, 2004). In the pages that follow, I begin to theorize "what's going on with whiteness" (hooks, 1990:54) in one concrete context. Following a demand articulated by Toni Morrison, this paper aims to uncover some of the ways in which racist ideology has impacted on "the mind, imagination and behavior" of "white' East German workers (Morrison, 1992: 12). I propose a historical materialist framework to capture some of the contradictions of 'unification' (particularly in relation to the hegemonic idea of 'whiteGermanness') and the ways in which 'white' East German workers experienced them. 


\section{Towards a Historical Materialist Approach to Racism \\ in Post-'Unification' Germany}

\section{Theoretical Framework}

The theoretical framework of historical materialism allows for a nuanced theorization of the relation between cultural change and what is often inadequately described as more material (e.g. economic and/or political) changes (Williams, 1997). As Ellen Meiksins Wood has convincingly argued, "base and superstructure" should be and have been conceptualized by some Marxists as "a continuous structure of social relations and forms with varying degrees of distance from the immediate processes of production and appropriation, beginning with those relations and forms that constitute the system of production itself" (Wood, 1995: 25-26). This is to say that capitalist social relations are not confined to any one societal sphere (e.g. the economic, political, cultural and/or domestic sphere). For the purposes of this paper, a historical materialist approach highlights the historical continuities and changes pertaining to complex and historically specific social relations in their connection to the idea of Germanness.

Also integral to this conception of history, social relationships are conceptualized as "embodied in real people and in a real context" (Thompson, 1980: 8). This is to say that the idea of Germanness is firmly situated within and dialectically related to lived experiences. Theorizing social change thus requires to draw out the connections between people's changing life-experiences and the cultural means with which people have made sense of these experiences (Thompson, 1980). Robert Miles argues that racism is "practically adequate" (Miles, 1989: 80), i.e. because it seems to describe and explain, racist ideology might constitute a cultural means with which people can make sense of their lived experiences. But with experiences (and interests) being class-specific, so are the respective cultural means. This is to say that I share with other Marxists the conviction that classspecific studies of racism are necessary.

Explaining racism in post-'unification' Germany further necessitates to account for the fact that, to paraphrase Marx, people make their own history although in conditions not of their own choosing. ${ }^{5}$ 'Unification' set in motion a process of re-constituting the 'German nation' on various levels. A re-ordering of hierarchical social relations of power was involved as well as shifts in the idea of Germanness. The Gramscian conception of common sense is important here. It denotes a "conception of the world which is uncritically absorbed by the various social and cultural environments in which the moral individuality of the average man [sic!] is developed." Influenced by the ways in which the world is conceptualized by intellectuals and high culture, "common sense is an ambiguous,

\footnotetext{
${ }^{5}$ Marx writes in The Eighteenth Brumaire of Louis Bonaparte: "Die Menschen machen ihre eigene Geschichte, aber sie machen sie nicht aus freien Stücken, nicht unter selbstgewählten, sondern unter unmittelbar vorgefundenen, gegebenen und überlieferten Umständen." (my emphasis). This has been translated as: "Men make their own history, but they do not make it as they please; they do not make it under self-selected circumstances, but under circumstances existing already, given and transmitted from the past." (Marx, 1994:15). What is important to note is that "Menschen" does not have a gender connotation - as the translation into English suggests. Rather, "Mensch" refers to the species of human beings and not a particular group of that species alone.
} 
contradictory and multiform concept" (Gramsci, 1999: 419-420, 423). In the face of a common sense association of 'German' and 'white', it is necessary to deal not only with the practice of the dominant group or ruling class. The agency of the working class needs to be taken seriously too, because workers "are historical actors who make (constrained) choices and create their own cultural forms" (Roediger, 1999: 9).

Neither nation-states nor nations exist as some natural, fixed entity ${ }^{6}$ but are made in historically specific contexts. Theorizing the connections between racism and 'unification' is to theorize how 'unification' impacted on the hegemonic idea of Germanness. One question I begin to explore concerns the role that the German state - particularly with respect to citizenship regulations - played. Yet I am convinced that it is not sufficient to focus on the German state alone to explain why and how a specific idea of Germanness materialized at different points in time. Theorizing social and cultural change requires going beyond the formal political sphere and allowing for the possibility that the national self was re-constituted from above and from below. Taking seriously the agency of the 'white' East German working class in the social construction of Germanness, leads to the following question: Why and how have 'white' East German workers in post-'unification' Germany come to the conclusion that their 'Germanness'/'whiteness' is meaningful??

Although writing about a different historically specific context, the work of W.E.B. $\mathrm{Du}$ Bois and David R. Roediger provides valuable insights as to how to theorize the dialectics of class and 'race' in relation to 'white' East German workers. Theorizing Black Reconstruction in America (1860-1880), Du Bois writes that "a sort of public and psychological wage" compensated "the white group of laborers" for the low monetary wage they received. Clarifying what this 'sort of public and psychological wage' entailed, Du Bois makes reference to "public deference and titles of courtesy" and further, alludes to the centrality of the right to vote. He argues that it was the vote of the "white group of laborers" which "selected public officials, and while this had small effect upon the economic situation, it had great effect upon their personal treatment and the deference shown them" (Du Bois, 1962: 700-701). In his Wages of Whiteness, Roediger (1999) would later emulate Du Bois's approach.

\footnotetext{
${ }^{6}$ Authors working within various theoretical frameworks have come to work with a conception of nation that emphasizes its social construction. One author even speaks of "the social constructionist paradigm" (Räthzel, 1995: 162). Its widespread acceptance (among scholars who sharply disagree on many issues) can easily be illustrated. For example, M. Rainer Lepsius describes the nation as a "conceived order" (Lepsius, 2004: 499), Benedict Anderson has coined the widely used phrase of the "imagined community" (Anderson, 1991), Eric Hobsbawm conceptualizes nation in terms of "social engineering" as well as "invented traditions" (Hobsbawm and Ranger, 1992) and Ernest Gellner writes: "Nationalism is not the awakening of nations to self-consciousness: it invents nations where they do not exist." (Gellner as quoted in Anderson, 1991: 6).

${ }^{7}$ This question is obviously an adaptation of the question which Roediger asks in his The Wages of Whiteness, i.e. "why and how [have] whites reach[ed] the conclusion that their whiteness is meaningful" (Roediger, 1999: 6).
} 
Having this framework travel to Germany, the argument speaks directly to an ambiguous practice that characterized 'unification': while GDR citizenship was automatically converted into 'unified'-Germany citizenship, the latter was not extended to many longterm residents (i.e. people who have lived there for decades or have been born in the country). I discuss this in more detail in the section on citizenship. Here it should suffice to say that 1989 marked a caesura for East German citizens in that their right to vote (the meaning of which clearly changed as parliamentary elections now involved an actual 'choice') made them the target of election campaigns. Political parties were competing for the votes of citizens and citizens only. This site and instance of inclusion/exclusion went unnoticed by neither citizens nor non-citizens (racialized as 'white' or non-'white').

Directly related to the particular distribution of the right to vote, is one level on which former GDR citizens became 'German' in an instant - without the qualifier East. As formally equal citizens, they have been included into the 'German nation'. But there is an uneasy relation between this formal equality ${ }^{8}$ and a dichotomy that took shape in the pre-'unification' FRG and that still structures ways of seeing: 'modern' or 'developed' West Germany vs. 'non-modern' or 'underdeveloped' East Germany. Here, the qualifier East continues to denote inferiority regarding their positioning in a hierarchy of various degrees of Germanness. And to add a third dimension of changes pertaining to the lived experiences of 'white' East German workers, they have had to come to terms with their individualized market dependence. Connected to the latter have been changes with regards to their subjective perception of (in-)dependence tied to which have been feelings of loss.

Linking the three themes of citizenship, the qualifier East and individualized market dependence, we begin to understand why and how the pleasures of 'Germanness' could function as a 'wage' for 'white' East German workers (Roediger, 1999: 13). The idea of 'whiteGermanness' has been part of the cultural means with which 'white' East German workers have made sense of the sweeping changes mentioned above. The concept 'wages of Germanness' is particularly useful in that it offers the possibility to theorize racism in relation to complex social relations. The latter are inscribed with political, ideological and economic dimensions, which themselves are inextricably intertwined. Building on the tradition of Du Bois (1962) and Roediger (1999), the concept 'wages of Germanness' revolves around the dialectics of 'race' and class. This dialectical relationship is key to grasping the historically specific ways in which 'white' East German workers have come to prize their 'whiteGermanness'. The 'wages of Germanness' are further of use in tackling the question how "[t]he 'spontaneous' consent given by the great masses of the population to the general direction imposed on social life by the dominant fundamental group" (Gramsci, 1999: 12) has been secured.

\footnotetext{
${ }^{8}$ Subjecting to critical scrutiny the claim of formal equality, there are a number of juridical-political issues that merit elaboration and critical discussion (e.g. certain Treuhand practices, Rückgabe vor Entschädigung etc.). But that would be the topic of another paper.
} 
Much of the mainstream literature speaks more or less directly to the re-nationalization of German identity in the wake of 'unification'. What is rarely theorized, though, are the tensions arising from the discrepancies between the previous construction of West German national identity (which relied on the 'othering' of East Germans) and the new reality of East and West Germans living in one Germany. And not nearly enough attention is paid to the extensiveness and complexity of the changes which East Germans have had to come to terms with. The contradictory process of 'unification' unfolded its dynamics within a context characterized by the historical legacy - in East and West - of a racialized idea of Germanness. The task is to grasp the connections between changes pertaining to the meaning of the idea of Germanness and the myriad of ways in which the every-day life experiences of 'white' East German workers changed. While this paper cannot provide a discussion as elaborate and thorough as the problematic calls for, it can suggest some entry points for further analysis: citizenship, the qualifier East and individualized market dependence.

\section{Citizenship and the Racialized Idea of ('White') Germanness}

Ideas about the 'German nation' - together with the idea of Germanness - have been renegotiated throughout history. This is to say that neither the 'German nation' nor the idea of Germanness have always already existed in one particular form. In the early 1990s, a hegemonic idea of Germanness materialized, which drew from a long history of racialized notions of Germanness. It is important to emphasize at this point that the idea of 'white' Germanness did not enter the stage of history in the 1990s for the first time. Historical research leaves no doubt that a sense of racial hierarchies has been embedded in notions of Germanness at least since German colonialism (El-Tayeb, 2005; Friedrichsmeyer et al., 1998; Geulen, 2004; Grosse, 2000; Mosse, 1978; Puschner, 2001; Zantop, 1997). Within the historically specific context of the early 1990s, Germanness was - to provide a snapshot-like image - commonly imagined as a subcategory of 'whiteness'. This is to say that being racialized as 'white' was (and is) a necessary precondition to pass as 'German' when the popular gaze swept by. But 'whiteness' alone was by no means sufficient as other 'qualifiers' demarcated the fiercely guarded terrain of Germanness. A few of these 'qualifiers' found juridical-political expression in German citizenship regulations, while other fine lines of distinction existed within the category 'white German' (which I refer to as degrees of Germanness).

When it comes to the idea of Germanness, citizenship regulations constitute an important case in point. "With the exception of the national socialist period", Fatima El-Tayeb points out, it was the nationality law of 1913 that was in effect until the 2000 reform. Only in 2000 were "certain persons of 'non-German blood' [granted] the right to citizenship". The Social Democrat/Green Party government, elected in 1998, "radically changed the law's exclusive jus sanguinis focus by granting citizenship to all persons born in Germany 
of parents legally living there for a certain period of time" (El-Tayeb, 2003: 483). And while the following discussion does not try to give a historical explanation of why or how German citizenship law developed the way it did, I would like to examine how citizenship shaped the ways in which people - particularly 'white' East German workers - came to think about Germanness in the early 1990s.

At that time, the German case was described as an example case of jus sanguinis, i.e. citizenship through descent (as opposed to jus soli, i.e. birthright citizenship). One writer goes as far as stating that "German citizenship law ... is based exclusively on jus sanguinis" (Brubaker, 1992: 82), thus contradicting another author who writes that "existing regimes have always mixed elements of 'civic' and 'ethnic' nationhood" (Smith, 2002: 110). While I do not want to engage in this debate, it should be emphasized that as 'unification' was underway, the German state conferred citizenship rights primarily through jus sanguinis. And it should be emphasized here that the German state was, without question, actively involved in re-constituting the idea of Germanness - not least through the legal stipulations concerning citizenship. The specific regulations meant that citizenship was transmitted by descent or parentage (with children of citizens or 'ethnic Germans' according to Article 116(1) of the German Constitution being considered 'German' and thus granted citizenship). In other words, by way of German citizenship being a 'blood right', the respective legal regulations and practices suggested that a person's Germanness was biologically determined.

As mentioned earlier, the citizenship law was not a novelty that was introduced during 'unification'. What changed in the early 1990s was the context - and so new dynamics were unleashed. Prior to 'unification', there were not only two German states but also two German citizenships. ${ }^{9}$ The interesting point here is that citizens of the GDR held GDR citizenship while from the West German side "the division of Germany never happened" with respect to citizenship (Brubaker, 1992: 82-83; Kurthen, 1997). Rather, there was an insistence on one German citizenship, which, of course, was closely related to the hegemonic ideology in West Germany that maintained, regardless of the founding of the GDR in 1949, that both East and West Germans belonged to one German nation. West German laws thus held that citizens of the GDR would automatically be granted citizenship in the FRG. These legal stipulations had been applied prior to 'unification' and further guided the granting of citizenship when the West German state expanded geographically to the East. To be clear, in the wake of 'unification' citizenship was automatically extended to GDR citizens. In this sense, East Germans moved up the ladder of Germanness.

Keeping in mind the close link between Germanness and 'blood' (as embedded in citizenship), this routine suggested that there was a biologically determinist subtext to the 'brothers and sisters' rhetoric. Notions of some common ancestry or, more crudely,

${ }^{9}$ I am not, perhaps ambiguously, considering Austria or Switzerland as German nation-states. 
some common bloodline were based on and reinforced a primordial idea of the German nation. The new (East German) citizens, in other words, essentially had been German all along (albeit, arguably, living in the 'wrong' state and without the 'proper' passport). Himani Bannerji's distinction between identities of being and identities of becoming offers a critical conceptual framework. Identities of being, she writes, "are about who we are, born into, originally and fundamentally". The underlying essentialist notion of personhood is tied to a static conception of identity, suggesting that the latter was fixed in time. In direct contrast, identities of becoming express "a creative and political need on someone's part". Here, the emphasis is on the changes pertaining to a person and her consciousness (Bannerji, 1993: xii-xiii). Within this framework, the practice of ascribing German citizenship to East German citizens suggested that being (considered) German constitutes an identity of being.

At the same time, the idea was evoked that not being (considered) German was also a question of being - and not of becoming. The inclusion of East German citizens stood in stark contradiction to the exclusion of many long-term residents of East and West Germany. Neither place of birth nor length of residence in the country nor social ties determined whether or not a person had the legal right to citizenship. The notion that Germanness was "innate and not to be acquired" (Pautz, 2005: 49), was clearly entrenched in legal stipulations. This is to say that embedded in citizenship law was a rejection of a conception of Germanness in terms of an identity of becoming. There is a dialectical relationship here between the biologically determinist underpinnings of the idea of Germanness and those of equally ingrained notions of 'foreignness'.

Writing about German colonialism, El-Tayeb emphasizes the racialized connotations of 'Germanness' and 'foreignness'. As "the cultural definition of Volk was gradually replaced by the biological one of race", she writes, a notion of "genetic, metacultural "foreignness", gained ground (El-Tayeb, 2005: 46). It is very well known that these racialized notions of the 'German nation' and of 'foreignness' found deadly articulations during German fascism. Yet it was as recent as the early 1990s that a chilling question appeared on antiracism posters in Berlin: "When you think, Who is German, is the thought in the back of your mind really, Who is Aryan?" (Wildenthal, 1997: 263). This question makes explicit the often-implied yet mostly unspoken notion of 'whiteness' that underlies the common sense understanding of the term 'German'.

Neither the term 'German' nor 'foreigner' has the same meaning for whoever uses it. Rather, I want to emphasize the multiaccentuality of signs - including words. As David McNally writes, "[w]hen we speak we do not simply enter a formal system called language ..., rather, we enter sites of struggle over meaning" (McNally, 2001: 116). The systemic nature of capitalism, which I referred to earlier, materializes not least in the form of 
ideological and discursive struggles - which are "inseparable from material-practical ones" (McNally, 2001: 118). Neither the hegemonic idea of Germanness nor the common sense notions of 'German' and 'foreigner' should therefore be naturalized. It is in a concrete historical context with specific social relations of power that particular meanings become hegemonic.

The hegemonic idea of Germanness is no exception. The common sense conflation of 'German' and 'Aryan' exists within a context that is characterized by a historically specific balance of power. Attempts to make non-'white' Germans (regardless of their status as citizen, permanent resident, refugee, etc.) invisible have been hegemonic - yet by no means uncontested - forces. Afro-Germans, for example, are "non-existent in the public mind" - despite, as El-Tayeb reminds us, having "lived in Germany at least since the fifteenth century" (El-Tayeb, 2005: 29). As the idea of non-'white' Germans is absent, recognition is withheld and anyone whose appearance is not 'German' in the sense of 'Aryan' is perceived as and named a 'foreigner' ('Ausländer'). Nora Räthzel captures this dialectical relationship as she describes the discourses on the nation and that on 'foreigners' as "opposite, but complementary" (Räthzel, 1995: 177). In other words, both discourses are internally related and function to secure racially homogenous views of the nation.

If the discourse on the German nation has mostly been silent about 'race' and 'whiteness' (a silence that has been fiercely defended), caution is warranted not to take this at face value. Naming "non-'Germanic' Germans” (El-Tayeb, 2005: 46) as 'foreigners' reveals the underlying racialization of those named 'foreigners' as well as 'Germans'. Notions of who is supposedly a 'foreigner' reveal that 'race' is implied - without necessarily being spoken - in relation to the idea of Germanness. To be sure, "whoever does not conform to a certain physical image of 'Germanness' is considered a 'foreigner'" (El-Tayeb, 2003: 463). The racially fixed representations of 'Germanness' and 'foreignness' speak of the impossibility to become German. Yet, in 1990, millions of GDR citizens became German citizens overnight.

The conditions under which people made sense of the peculiar citizenship regime are perhaps best described in terms of the contradiction between the actual multi-racial reality and a 'white'-washed common sense idea of Germanness. The latter does not exist as a 'free flowing' entity but rather as a set of cultural means with which people make sense of their experiences. ('White') GDR citizens experienced numerous instances in which they were assured - not least by Helmut Kohl, the chancellor during 'unification' - of being the 'brothers and sisters' of West Germans. The trope of the family is significant here as it reinforced somewhat fixed notions concerning who does (not) belong to the 'German nation'. Indeed, the assumption that ('white') East and West Germans belonged to one nation clearly became hegemonic. Naturalizing and normalizing 'unification', former 
chancellor Willy Brandt articulated a phrase that would become something like the slogan of 'unification': "Now grows together, what belongs together." ${ }^{10}$ But who was and who was not thought to 'belong'?

Citizenship regulations not only suggested that GDR citizens belonged as 'Germans'. Through their biologically determinist underpinnings the respective laws should also be read as the legal validation of collapsing nation and 'race'. If 'race' has often not been (explicitly) spoken in relation to the idea of Germanness, then due to 'German' having been seen as 'naturally white'. With 'foreigners' being constructed as the racialized 'other' of ('white') Germans, there were solid grounds for the common sense conflations - in East and West Germany - of 'German'/'white' as well as 'foreigner'/non-'white'. The opening excerpt of the poem "Blues in Black-and-White" speaks the unspoken as Ayim (1993) explicates the coloured line of inclusion and exclusion.

\section{The Qualifier East}

The category 'whiteGerman' - which includes 'white' East Germans - is ridden with hierarchical orderings. Prior to 'unification', West German national identity had been constructed against the East German 'other', i.e. "the assertion of East German inferiority was [vitally important] to the West German self-definition" (Rosenberg, 1991a: 21). At the same time, however, the East German 'other' was included when the construction of one 'German nation' was concerned. Further, unity of East and West constituted the core idea underlying claims that the two Germanys were part of one nation (Räthzel, 1995). This 'paradox' continued to exert its influence in post-'unification' Germany. Inextricably intertwined with this pre-existing 'paradox' is the epistemological structure that continues to construct East Germans as - in one way or another - 'lagging behind' West German society.

There are three ways, broadly speaking, in which hegemonic discourses construct East Germans in terms of 'belatedness'/'time-lag'. Reference is made to (1) East Germany's economic backwardness, (2) the 'time lag' of East Germans in political terms (supposedly 'they' are not being committed to democracy yet) and/or (3) some "ugly nationalist strain among disadvantaged youths" (Jarausch and Geyer, 2003: 240) - to which, it is claimed, greater resistance exists in West Germany. This points to the necessity to theorize the hierarchy within the category 'whiteGerman'.

'White' East Germans are considered 'German' as they are racialized as 'white' and do hold German citizenship. But the insistence on the qualifier East suggests that there are various degrees of Germanness - the "scale" of which was developed prior to 'unification'. As Dominic Boyer writes, "[p]ositive and negative poles of cultural Germanness were distilled on both sides of the Wall" (Boyer, 2006: 13). Since 'unification' the discourses

${ }^{10}$ This is the rough translation of "Jetzt wächst zusammen, was zusammen gehört." 
of the 'winners' (i.e. West Germany) have become hegemonic and thus East Germans are re-presented in terms of the "national-cultural past" of Germany, particularly "German "authoritarian traditions" (Boyer, 2006: 13). Considering the intricate ways in which the idea of Germanness has historically implicated cultural and racial traits (El-Tayeb, 2005), the tensions between the racial inclusion and cultural 'othering' of 'white' East Germans warrant attention.

'White' East Germans are 'othered' in relation to 'white' West Germans. Yet the former are considered 'whiteGerman' in contrast to non-'white' people. They are, in other words, at the same time 'other' and 'German' - which needs to be theorized further. Here it should suffice to say that the relational aspect is absolutely central. Lived experiences in hierarchically ordered societies shift with the answer given to the question: position in relation to who? In terms of the positioning of 'white' East Germans within a racialized/ culturalized hierarchy, the contradictions arising from being considered 'German' (and as such at times actively participating in 'othering') yet not quite as 'German' need to be kept in mind.

More often than not, constructions of East Germans rely to some degree on a particular notion of the forty years of GDR history. Indeed, looking at the social relations in post'unification' Germany through the lens of how history is written, illustrates vividly how the latter is utilized to stabilize the status quo. To begin with, the hegemonic re-presentation of history underwent significant changes in the early 1990s. For a brief moment in 1989/1990, East Germans were in fact celebrated as heroes who had brought down an oppressive state. But this would quickly change (Fulbrock, 1997). In her article "The Colonization of East Germany", Dorothy Rosenberg argues that "the speed of German political and economic union was dictated by the fear that a popularly elected socialist government might stabilize the GDR as an independent entity" (Rosenberg, 1991a: 23). The image of heroes had to and in fact was rapidly undone by way of zooming in on two questions directed at East Germans: Did 'they' really find it morally defendable to have lived in the GDR for so long and perhaps to have been happy from time to time? And after all, what had 'they' actually done, considering that the GDR had collapsed on its own (Scherer, 2000)?

In light of the supposedly superior (West German) system failing to garnish the fullfledged support of East Germans, it became accepted to question whether the East German 'brothers and sisters' were in fact only part of the extended family, i.e. not really 'brothers and sisters' but rather distant cousins (Ahbe, 2004). As the supposed deficits of East Germans became central, it also became common practice to localize racism as an entirely East German problem. Allegedly, being socialized within the 'totalitarian' system of the GDR had led to a ('cultural') difference in 'values' and 'norms'. 'White' East Germans are not quite as German as 'white' West Germans. Based on the common 
argumentative structure, which reasserts the trope of West German superiority and East German inferiority, the 'problem' at hand can be externalized (i.e. external to West German society). It should be noted here that the various degrees of Germanness are dialectically related to the regularly needed dose of narcissist affirmation concerning West German society's superiority (Rommelspacher, 1992). Simultaneously, it becomes possible to exorcise "the spectre of capitalism" (Lazarus, 2002: 46) out of discussions on racism in post-'unification' Germany. In short, the East in East German clearly continues to matter.

In the face of such contextualization, we can begin to see that the idea of Germanness provides 'white' East Germans with the possibility to break out of the inferiority that is continuously projected onto them. In a recent article, Betsy Esch and David Roediger suggest that "racist acts are sometimes or maybe often acts of racial empowerment" (Esch and Roediger, 2006: 7). In the case of 'white' East Germans this seems to find substantiation. By way of self-identifying as 'whiteGerman', it could be hoped to have access to the one source of power - however mysterious - that was made readily available (although in contradictory ways). This one source of power originates in their being racialized as 'white' and being German citizens (Rommelspacher, 1992). As complex as social relations of power, the impetus to seek 'racial empowerment' can be expected to stem from class, 'race', gender, sexuality, ability etc. But if this illustrates that "race and racism grow and develop beyond the specific relations of production or reproduction" (Esch and Roediger, 2006: 7 [my emphasis]), this is not to say that the specific relations of production and reproduction were irrelevant. Bringing capitalism back in, what I call (obviously building on Du Bois's and Roediger's work) the 'wages of Germanness' can be seen to compensate not only for the inferiority projected onto East Germans.

\section{Individualized Market Dependence}

The analysis now shifts slightly as class is more explicitly brought into focus. Taking inspiration from Roediger's The Wages of Whiteness (1999), these last pages focus on the connections between the 'wages of Germanness' and changes pertaining to East German workers' control over their lives prior and subsequent to 'unification'. Roediger argues that in the US in the 19th century, new connections were made between 'whiteness' and "a defense of one's independence as a worker" in light of "new forms of capitalist labor discipline" (Roediger, 1999: 20-21). With experiencing - and often internalizing - capitalist labour discipline often came some sense of loss. In the US context, the "preindustrial past that they [a very diverse white working class] scorned and missed" would be projected onto 'black' bodies. Thus, "white male anxieties" (themselves directly related to capitalist discipline) would become tied to new articulations of "the idea of blackness" (Roediger, 1999: 97). Now obviously, life in the GDR should not be conceptualized as pre-industrial (Fulbrook, 2005). But the notion of loss in conjuncture with new meanings of labour discipline are absolutely relevant when it comes to the changes associated with 'unification'. 


\section{Towards a Historical Materialist Approach to Racism in Post-'Unification' Germany}

In the GDR, most people worked for wages and it was often through their workplace that they would have access to other things (ranging from social networks to cultural engagement, vacation spots and summer camps for children). 'Unification' altered the meaning of work/employment significantly as it came to be associated with a previously unknown sense of insecurity, related to individualized market dependence. ${ }^{11}$

A first case in point concerns the enormous lay-offs in the early 1990s. Capturing some of the scope of the 'economic transition' after 1989, Hajo Funke writes that in 1992 only $31 \%$ of people still held the same job as before 1989 . While some people found new jobs, many did not. The actual number of jobs has decreased by almost $40 \%$ or 3.5 million (Funke, 2002). This 'economic reconstruction' has not been gender-neutral considering, for example, that "at the end of 1994 women accounted for two-thirds of the unemployed and three-quarters of those out of work for more than a year" (Welsh, Pickel and Rosenberg, 1997: 116). ${ }^{12}$ The - however limited - sense of 'economic' security, which East Germans had previously known (particularly, the fact that the very experience of unemployment had been "unknown in the GDR"), was put into sharp relief by the new reality that came with the demise of the East German state (Rosenberg, 1991b: 131). The 'wages of Germanness' compensated East Germans for having had to accept a way of life in which the meaning of insecurity revolved around access to the means of subsistence (e.g. food, clothing, housing). This meaning of insecurity is to be distinguished from the previously existing notion that can be said to have revolved less around 'economic' and more around 'political' insecurity. From the perspective of many East Germans, the new notion of insecurity would become one of the defining features of 'unification' (it has been pointed out repeatedly that conversations at the time would often start with the question: "Do you still have a job?").

A second instance in which the new meaning of insecurity made itself felt is tied to the changed character of wage-labour. Arguably, people in the GDR (particularly able-bodied males) were forced to engage in wage-labour. But this was less an economic and more an extra-economic force, i.e. the police showing up at the door of adult males and exerting its authority - which is very different from the force exerted by 'the laws of the market'. (To be sure, the underlying notion here is that the East German state was not under the control of the direct producers - as the name workers' and peasants' state [Arbeiter- und Bauernstaat $]$ seemed to claim.)

\footnotetext{
${ }^{11}$ The literature on state capitalism suggests that the GDR as a state and society was market dependent with the main concern being the accumulation of capital. While I do not engage with this literature here, I do think that it is important to point out that in terms of the lived experience of workers in the GDR it does not make sense to assume that workers experienced the kind of individualized market dependence that is characteristic of life in post-'unification' Germany.

${ }^{12}$ Indeed, the effects of 'unification' on the meaning of guaranteed employment, affordable housing, free education, free medical care, paid parental leave, paid daycare, "provision of a state-subsidized hot meal to virtually everyone from two-year-olds in day car to home-bound pensioners" and availability of abortion on demand have clearly been gendered (Rosenberg, 1991b).
} 
The 'economic' changes brought about by 'unification' included the creation of conditions in which the material force of market dependence could come to fruition. Workers' market dependence materialized in the form of the individualized responsibility to find/keep a job. Individual market dependence constitutes an ever starker compulsion as alternative ways to gain access to the means of subsistence shrink (e.g. through neoliberal 'welfare reforms'). In order to gain access to the means of subsistence, propertyless individuals increasingly have no other choice but to engage in wage-labour. What is key concerning the changes in the lived experiences of East German workers is the economic compulsion in post-'unification' Germany - unlike the extra-economic force exerted in the GDR that forces propertyless people to sell their labour-power. The workers do not need to be harassed into working for wages by the police as they are disciplined through their individualized market dependence in conjuncture with their propertylessness. ${ }^{13}$

Roediger's analysis of the "formation of the first American working class" suggests that there was a connection between 'white' workers' "struggle for success", their "fears of cultural inferiority" and their "desire to project onto Blacks" certain behaviours. The "specific behaviors" projected onto black bodies were those, which brought to white workers "conflicted emotions" - conflicted because capitalist labour discipline pulled individual workers in three directions, i.e. (1) compliance, (2) resistance and (3) tradition (Roediger, 1999: 96-97). Looking at East German workers, I believe that a very similar dynamic can be detected.

First, in relation to compliance, East German workers have clearly been pulled (and pushed) to internalize the new way of life. The successful pull towards compliance has materialized in attempts to live according to the rules of capitalist democracy. This is to say that East German workers have had to come to terms with new social relations - including "radically different value systems" (Scott, 2002: 172). A key case in point in this regard concerns a particular sense of individualism (related to the primacy of selfinterest), which is directly tied to the notion that the capitalist market rewards the "hard working' individual.

Second, resistance or defiance has materialized in various forms of individual and collective action. The electoral success of the PDS (Party of Democratic Socialism, which emerged out of the Socialist Unity Party) might be an expression of this sentiment as are the protests against the welfare reform Hartz IV. Thirdly, the widely recognized nostalgia for the East German past (Ostalgie) can be considered a form in which tradition has exerted its pull. This pull towards the past often involves some feelings of nostalgia and a kind of mourning for the perceived sense of a lost community and a sense of a lost (market) independence. Resistance and tradition can both be considered to have contributed to what

\footnotetext{
${ }^{13}$ To elaborate on this notion of market dependence, it is a central aspect of life in capitalism that propertyless producers are economically forced to engage in wage-labour. In Capital, Marx writes explicitly about the "economic bondage" of the wage-labourer (Marx, 1976: 723).
} 


\section{Towards a Historical Materialist Approach to Racism \\ in Post-'Unification' Germany}

might best be described as an obsessively entertained discourse around the question why East Germany 'deviates' from West Germany concerning the effects of market society and democracy. As Thomas Ahbe reveals, this question zooms in on the 'uniqueness' (Einzigartigkeit) - not to say 'otherness' - of East Germans (Ahbe, 2004: 19).

'White' East Germans projecting certain anxieties arising from the tensions between compliance, resistance and tradition onto 'others' is not a historical novelty, as Roediger's work illustrates. In the German case it is, however, a project yet to be undertaken to research in more detail the concrete links between the conflicted emotions and the construction of the dualism 'whiteGermanness' vs. 'foreignness'.

\section{Conclusion}

What is the relationship between the violence against non-'white' people and German 'unification'? Ignorant of the long history of the term 'German' as what Roediger might call a "racially inflected term" (Roediger, 2005: 5), the hegemonic discourse suggests that racism could be spatially fixed as an entirely East German 'problem'. As the cause of racism is apparently 'found' in the past and/or culture of East Germans, the historical legacy and the recent changes pertaining to the idea of Germanness fall off the radar screen. Also, the door is closed to interrogate the new conditions of life related to 'unification' and the ways in which 'white' East German workers (and other people living in Germany) have made sense of their experiences. In contrast, the conceptual tool 'wages of Germanness' allows us to identify key sites of inclusion and exclusion, theorize social relations of power/ruling and to capture the changes in life-experiences as well as the associated cultural changes.

While the paper began with a brief overview of the contradictory meanings of the term 'unification', it focussed largely on the underlying contradictory reality. More research is needed in order to further theorize the social relations of racialized (as 'white' or non'white') East and West German workers. For example, this paper has focussed on 'white' East German working people but it should be mentioned that the notion of 'economic' insecurity - as rooted in individualized market dependence - has been reshaped (although not in the same ways) for 'white' and non-'white', East and West German workers. ${ }^{14}$ Without questioning the ideology that continuously assures 'whiteWestGermans' - without differentiating along the lines of class - of its superiority, it is unlikely that (a) the hegemonic understanding of 'German' as 'white' is effectively criticized and that (b) meaningful class solidarity - among 'white' and non-'white' East and West German workers - is built. Anti-racism is absolutely crucial to undoing the hierarchical ordering within the German working class - the perception thereof as well as its materiality.

\footnotetext{
${ }^{14}$ For example, neoliberal projects of 're-structuring' the welfare state have meant that previous notions of 'economic' security were robbed of their material basis.
} 


\section{REFERENCES}

Ahbe, T. 2004. "Die Konstruktion der Ostdeutschen: Diskursive Spannungen, Stereotype und Identitäten seit 1989." Aus Politik und Zeitgeschichte, Vol. 54, No. 41-42, pp. 12-22.

Ahbe, T. 2000. "Wilde Zucht der Muttermale: Ursachenforschung." Freitag: Die OstWest-Wochenzeitung. No. 34, <http://www.freitag.de/2000/34/00340502.htm> (August 29, 2005).

Anderson, B. 1991. Imagined Communities: Reflections on the Origin and Spread of Nationalism. London: Verso.

Ayim, M. 1993. "Das Jahr 1990: Heimat und Einheit aus afro-deutscher Perspektive.” In Entfernte Verbindungen: Rassismus, Antisemitismus, Klassenunterdrückung. I Hügel, C. Lange, M. Ayim, I. Brubeck, G. Aktas and D. Schultz (eds.). Berlin: Orlanda Frauenverlag, pp. 208-214.

Bannerji, H. 1993. The Writing on the Wall: Essays on Culture and Politics. Toronto: TSAR Publications.

Boyer, D. 2006. "Ostalgie and the Politics of the Future in East Germany." Paper presented at the international conference Post-Communist Nostalgia (7-8 April 2006 at the University of Illinois, Urbana-Champaign). <http://www.reec.uiuc.edu/events/ Conference/boyer.pdf $>$ (July 18, 2006).

Brubaker, R. 1992. Citizenship and Nationhood in France and Germany. Cambridge: Harvard University Press.

Callinicos, A. 1991. The Revenge of History: Marxism and the East European Revolutions. University Park, Pennsylvania: The Pennsylvania University Press.

Çil, N. 2005. "Der andere und der fremde Aussenseiter: Türkische Nachkommen im wiedervereinigten Deutschland." In Insider - Outsider: Bilder, ethnisierte Räume und Partizipation im Migrationsprozess. IFADE (ed.).Bielefeld: transcript Verlag, pp. 57-79.

Du Bois, W.E.B. 1962. Black Reconstruction in America: An Essay Toward a History of the Part Which Black Folk Played in the Attempt to Reconstruct Democracy in America, 1860-1880. New York: Russell \& Russell, Inc. 
El-Tayeb, F. 2005. "Dangerous Liaisons: Race, Nation, and German Identity" In Not So Plain As Black And White: Afro-German Culture and History, 1890-2000. P. Mazón and R. Steingröver (eds.). Rochester: University of Rochester Press, pp. 27-60.

El-Tayeb, F. 2003. "'If You Can't Pronounce My Name, You Can Just Call Me Pride': Afro-German Activism, Gender and Hip Hop," Gender \& History, Vol. 15, No. 3, pp. $460-486$.

Esch, B. and D.R. Roediger. 2006. "Non-racialism through Race (and Class)". New Socialist: Ideas for Radical Change, No. 56, pp. 6-10.

Eggers, M. M., G. Kilomba, P. Piesche and S. Arndt. 2005. Mythen, Masken und Subjekte: Kritische Weissseinsforschung in Deutschland. Münster: UNRAST-Verlag.

Friedrichsmeyer, S., et al. 1998. Imperialist Imagination: German Colonialism and Its Legacy. Ann Arbor: The University of Michigan Press.

Fulbrook, M. 2005. The People's State: East German Society from Hitler to Honecker. New Haven: Yale University Press.

Fulbrook, M. 1997. "Reckoning with the Past: Heroes, Victims, and Villains in the History of the German Democratic Republic.” Rewriting the German Past: History and Identity in the New Germany. R. Alter and P. Monteath (eds.). New Jersey: Humanities Press, pp. 175-196.

Geulen, C. 2004. Wahlverwandte: Rassendiskurs und Nationalismus im späten 19, Jahrhundert. Hamburg: Hamburger Edition.

Gramsci, A. 1999. Selections from the Prison Notebooks. Q. Hoare and G.N. Smith (eds.). New York: International Publishers.

Grosse, P. 2000. Kolonialismus, Eugenetik und bürgerliche Gesellschaft in Deutschland 1 850-1918. Frankfurt: Campus Verlag.

Guillaumin, C. 2000. "Zur Bedeutung des Begriffs 'Rasse'," Theorien über Rassismus. N. Räthzel (ed.). Hamburg: Argument Verlag, pp. 34-42.

Hobsbawm, E. and T. Ranger (eds.). 1992. The Invention of Tradition. Cambridge: Cambridge University Press.

hooks, b. 1990. Yearning: Race, Gender, and Cultural Politics. Boston: South End Press. 
Jarausch, K.H. and Geyer, M. 2003. Shattered Past: Reconstructing German History. Princeton: Princeton University Press.

Kurthen, H. 1997. "Defining the Fatherland: Immigration and Nationhood in Pre- and Postunification Germany." In Rewriting the German Past: History and Identity in the New Germany. R. Alter and P. Monteath (eds.). New Jersey: Humanities Press, pp. 65-102.

Lazarus, N. 2002. "The Fetish of 'the West' in Postcolonial Theory." In Marxism, Modernity, Postcolonial Studies. C. Bartolovich and N. Lazarus (eds.). Cambridge: Cambridge University Press, pp. 43-64.

Lepsius, M.R. 2004. "The Nation and Nationalism in Germany." Social Research, Vol. 71, No. 3, pp. 481-500.

Marx, K. 1976. Capital: A Critique of Political Economy, Volume 1. London: Penguin Books.

Marx, K. 1994. The Eighteenth Brumaire of Louis Bonaparte. New York: International Publishers.

McNally, D. 2001. Bodies of Meaning: Studies on Language, Labor, and Liberation. Albany: State University of New York Press.

Miles, R. 1989. Racism. New York: Routlegde.

Morrison, T. 1992. Playing in the Dark: Whiteness and the Literary Imagination. Cambridge: Harvard University Press.

Mosse, G.L. 1978. Toward the Final Solution: A History of European Racism. New York: Howard Fertig.

Opitz (Ayim), M. 1992. "Blues in Black-and White" (poem translated by Tina Campt). In Showing Our Colors: Afro-German Women Speak Out. M. Opitz, K. Oguntoye and D. Schultz (eds.). Amherst: The University of Massachusetts Press, p.232-233.

Pautz, H. 2005. "The Politics of Identity in Germany: the Leitkultur debate." Race \& Class, Vol. 46, No. 4, pp. 39-52.

Puschner, U. 2001. Die völkische Bewegung im wilhelminischen Kaiserreich: Sprache - Rasse-Religion. Darmstadt: Wissenschaftliche Buchgesellschaft. 
Räthzel, N. 1995. "Nationalism and Gender in West Europe: the German Case" In Crossfires: Nationalism, Racism and Gender in Europe. H. Lutz, A. Phoenix and N. Yuval-Davis (eds.). London: Pluto Press, pp. 161-189.

Roediger. D.R. 1999. The Wages of Whiteness: Race and the Making of the American Working Class. London: Verso.

Roediger. D.R. 2005. Working Toward Whiteness: How America's Immigrants Became White: The Strange Journey from Ellis Island to the Suburbs. New York: Basic Books.

Rommelspacher, B. 1992. "Rechtsextremismus und Dominanzkultur." In A. Foitzik et al. (eds.). "Ein Herrenvolk von Untertanen": Rassismus - Nationalismus - Sexismus. Duisburg: Diss.

Rosenberg, D. 1991a. "The Colonization of East Germany." Monthly Review, Vol. 43, No. 4, pp. 14-33.

Rosenberg, D. 1991b. "Shock Therapy: GDR Women in Transition from a Socialist Welfare State to a Social Market Economy.” Signs, Vol. 17, No. 1, pp. 129-151.

Scherer, R. 2000. "Zu den wissenschaftlichen Analysen des Herbstes '90: Grundmuster der Diskussion.” In Wir hatten Hoffnung aufeine Demokratie: Rostocker Protestenten im Herbst '89. S. Höser and R. Scherer. Mössingen-Talheim: Talheim Verlag, pp. 11-28.

Scott, H. 2002. "Was there a Time before Race? Capitalist Modernity and the Origins of Racism." In Marxism, Modernity, Postcolonial Studies. C. Bartolovich and N. Lazarus (eds.). Cambridge: Cambridge University Press, pp. 167-182.

Smith, R.M. 2002. "Modern Citizenship.” In Handbook of Citizenship Studies. Isin, E.F. and Turner, B.S. (eds.). London: Sage Publications, pp. 105-115.

Thompson, E.P. 1980. The Making of the English Working Class. New York: Penguin Books.

Wachendorfer, U. 2004. "Weiss-Sein in Deutschland." In TheBlackBook: Deutschlands Häutungen. AntiDiskriminierungsBüro (ADB) Köln von Öffentlichkeit gegen Gewalt e.V. and cyberNomads (cbN) (eds.). Frankfurt am Main: IKO-Verlag für Interkulturelle Kommunikation, pp. 116-129. 
Welsh, H.A., A. Pickel and D. Rosenberg. 1997. "East and West German Identities: United and Divided?” In After Unity: Reconfiguring German Identities. K.H. Jarausch (ed.). Providence: Berghan Books, pp. 103-136.

Wildenthal, L. 1997. "Race, Gender, and Citizenship in the German Colonial Empire" In Tensions of Empire: Colonial Cultures in a Bourgeois World. F. Cooper and A.L. Stoler (eds.). Berkeley: University of California Press. pp. 263-283.

Williams, R. 1997. Problems in Materialism and Culture. London: Verso.

Wood, E. M. 1995. Democracy against Capitalism: Renewing Historical Materialism. Cambridge: Cambridge University Press.

Zantop, S. 1997. Colonial Fantasies: Conquest, Family, and Nation in Precolonial Germany, 1770-1870. Durham: Duke University Press. 